\title{
Synopsis of Martinella Baill. (Bignonieae, Bignoniaceae), with the description of a new species from the Atlantic Forest of Brazil
}

\author{
Alexandre R. Zuntini', Lucia G. Lohmann' \\ I Departamento de Botânica, Instituto de Biociências, Universidade de Sáo Paulo, Rua do Matão, 277, \\ 05508-090, São Paulo, SP, Brazil \\ Corresponding authors: Alexandre R.Zuntini (zuntini@gmail.com); Lucia G. Lohmann (llohmann@usp.br) \\ Academic editor: A. Paton | Received 1 January 2014 | Accepted 1 April 2014 | Published 9 May 2014 \\ Citation: Zuntini AR, Lohmann LG (2014) Synopsis of Martinella Baill. (Bignonieae, Bignoniaceae), with the \\ description of a new species from the Atlantic Forest of Brazil. PhytoKeys 37: 15-24. doi: 10.3897/phytokeys.37.6940
}

\begin{abstract}
Martinella has traditionally included two species, Martinella iquitoensis and Martinella obovata, that are characterized by the presence of interpetiolar ridges surrounding the stems and minute prophylls of the axillary buds. A third species, Martinella insignis, is here described as new, illustrated and compared to other species in the genus. Martinella insignis is the first record of the genus in the Atlantic Forest of Brazil, and differs from other species of Martinella by the yellow corolla (vs. red to dark purple) and 5-lobed calices (vs. 2-4-lobed).
\end{abstract}

\section{Keywords}

Martinella, Bignonieae, Bignoniaceae, Neotropics, Brazilian Atlantic Forest

\section{Introduction}

Martinella Baill. (1888) is strongly supported as monophyletic by molecular data (Lohmann 2006). Species of Martinella are well distinguished by the combination of minute triangular prophylls of the axillary buds, an interpetiolar ridge surrounding the stem, and bilobed or (2-)4-parted calyces (Lohmann and Taylor 2014); the latter two being considered putative synapomorphies of the genus (Lohmann 2006; Lohmann 
and Taylor 2014). In addition to these features, the basal tubular portion of the corolla is slightly longer and much narrower than the calyx, leaving it loose within the calyx, while the upper portion of the corolla tube is abruptly inflated and campanulate, up to four times wider than the tubular portion (Fig. 1D). Gentry (1974) described this corolla morphology plus the red to purple color as a Martinella-type flower, and hypothesized that this flower was associated with pollination by hummingbirds. The only exception to Gentry's floral description is the position of the anthers (exserted or subexserted), which are always included in Martinella.

The genus as currently circumscribed includes two species of neotropical lianas (Lohmann and Ulloa Ulloa 2013; Lohmann and Taylor 2014): Martinella iquitoensis A.Samp., restricted to the Amazon basin (Brazil, Colombia, Ecuador, Peru and Venezuela) and Martinella obovata (Kunth) Bureau \& K.Schum., ranging from Central America to Northern South America and the Amazon basin (Lohmann et al. 2013). A third morphologically distinct species of Martinella was discovered during fieldwork in the Atlantic Forest of Brazil; its description here extends the known range of this genus. Here we present an overview of the genus and the separation of its species.

\section{Materials and methods}

This work is based on the study of herbarium collections of Martinella deposited in CEPEC, MBM, MBML, MO, NY, RB, SPF and VIES (herbarium acronyms follow Thiers 2013). Morphological descriptions are based on dried specimens, and follow the terminology of Radford et al. (1974). The parentheses in the descriptions indicate rare conditions. Micrographs of selected structures were made using a stereomicroscope and digitally processed through focus stacking. For the species distribution map, the geographical data of $M$. insignis were combined with those used in Lohmann et al. (2013) and plotted over a digital elevation model (GTOPO 30, available from the U.S. Geological Survey).

\section{Taxonomic treatment}

Martinella Baill., Hist. Pl. 10: 30.1888.

http://species-id.net/wiki/Martinella

Type. Martinella martinii (DC.) Baill. ex K. Schum. (= Martinella obovata (Kunth) Bureau \& K. Schum)

Lianas. Roots with tuberous portions. Branches terete, glabrous or puberulous, with trichomes simple or stipitate-glandular, with continuous interpetiolar ridges, without interpetiolar glands; prophylls minute, triangular, glabrous or puberulous. Leaves 3-foliolate or 2-with the terminal leaflet modified into a simple or trifid tendril; leafets membranous to coriaceous, margins entire (sinuate), with or without mite-domatia, 
glabrous to puberulous, with glands on adaxial surface. Inflorescences axillary, arranged in racemes, panicles, thyrses or compound dichasia. Flowers with calyx tubular (campanulate), bilobed, irregularly 2-4-lobed, or 5-lobed, with lobes rounded or aristate, membranous, with few scattered glands; corolla deep purple, red or yellow, tubular in the basal portion and campanulate in the upper part, straight to weakly curved, membranous, glabrous outside, glabrous inside except with few glandular trichomes at stamen insertion; stamens included, glabrous, pollen in monads; ovary terete, smooth, glabrous or lepidote, with a single series of ovules on each placenta, style glabrous, stigma rhombic, glabrous. Capsules drying dark brown, linear, flattened, smooth, glabrous or puberulous, with calyx caducous; seeds oblong, winged, with wings opaque.

Martinella comprises three species, distributed from Mexico to eastern Brazil. The main features that distinguish the species are summarized in Table 1 and outlined in the key below.

\section{Key to species of Martinella}

$1 \quad$ Calyx 5-lobed; corolla yellow; eastern Brazil 1. M. insignis

1' Calyx 2-4-lobed; corolla deep wine to red; Antilles, Central America and Northern South America through Amazon basin . .2 Inflorescence arranged in thyrse or panicle; leaflet with cuneate base

2. M. iquitoensis

2' Inflorescence arranged in raceme; leaflet with cordate to truncate or rarely cuneate base

3. M. obovata

\section{Martinella insignis A.H. Gentry ex Zuntini \& L.G. Lohmann, sp. nov. urn:Isid:ipni.org:names:77138471-1 http://species-id.net/wiki/Martinella_insignis}

Figs $1-2$

Type. BRAZIL. Bahia: Itamaraju, Rodovia Itamarajú-Teixeira de Freitas, $3 \mathrm{~km}$ de Itamaraju (BR-101). Fazenda Chapadão, 3 November 1983, R. Callejas, A. M de Carvalho \& L. M. Silva 1629 (holotype MBM-94960!; isotypes CEPEC not seen, MO3600686!, NY-00483568!, RB-232556!).

Diagnosis. Martinella insignis differs from $M$. iquitoensis and $M$. obovata by its 5-lobed calyces and yellow corollas, in contrast to 2-4-lobed calyces and dark purple to red corollas in these other species (Table 1).

Description. Lianas. Branches green, drying brownish, striated, densely covered with stipitate-glandular trichomes when young; prophylls $0.7-1.5 \times 1.0 \mathrm{~mm}$, densely covered with stipitate glandular trichomes, without patelliform glands (with few patelliform glands). Leaves 2 -foliolate with the terminal leaflet generally modified into a trifid tendril; petioles terete, 34-64 mm long, covered with stipitate glandular trichomes; petiolules terete, 14-42 mm long, covered with stipitate glandular trichomes; 


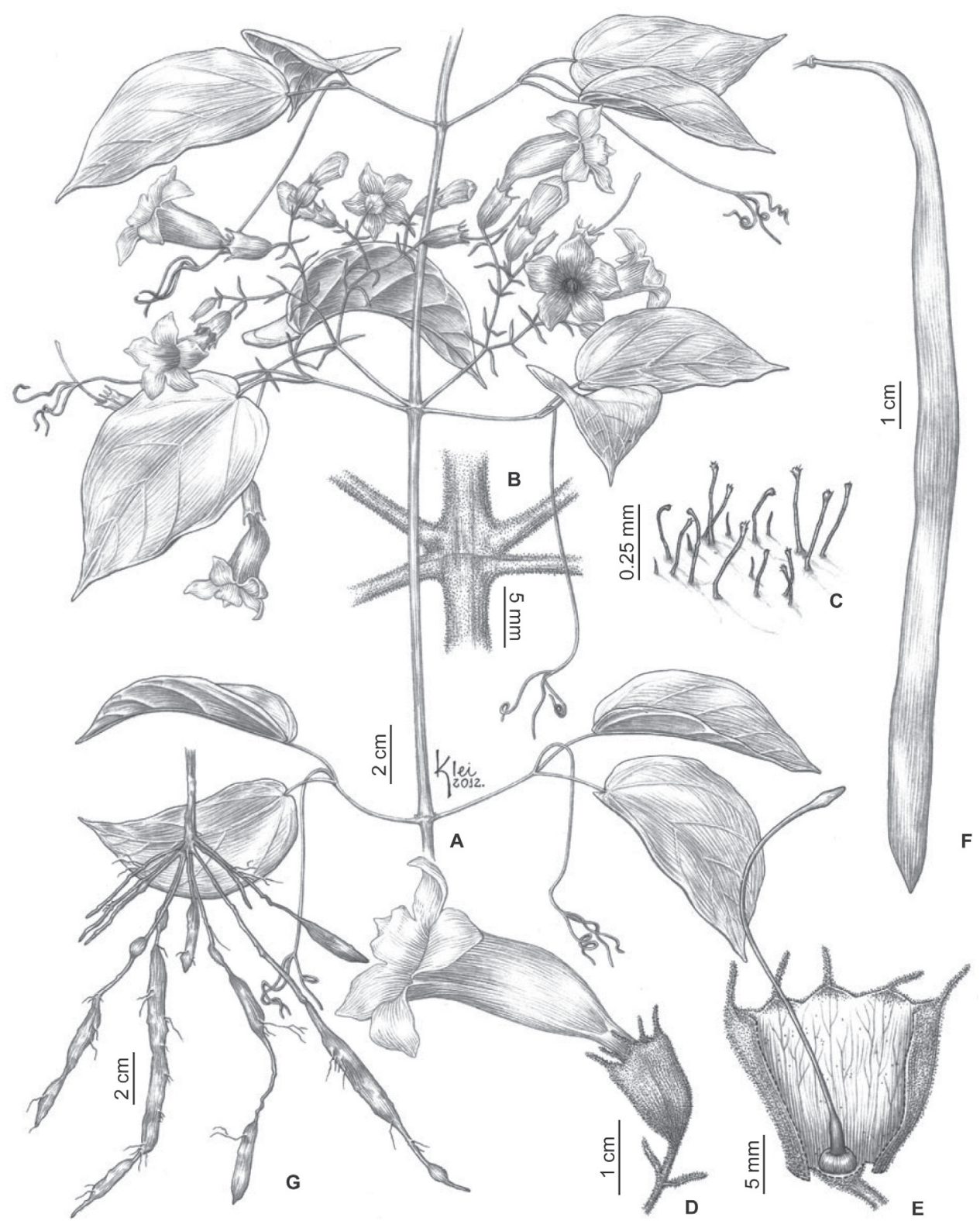

Figure I. Morphology of Martinella insignis: A Habit B Node with interpetiolar ridge C Glandular stipitate trichomes D Flower (lateral view) E Calyx (opened) and gynoecium F Fruit G Root system with tuberous portions. From Zuntini 151 (A-E), Sucre 5519 (F) and Zuntini 321 (G).

leaflets weakly discolorous, membranous, ovate, with a long acuminate to caudate apex and a cordate base, margins entire (sinuate), 7.6-11.8 $\times 3.4-6.4 \mathrm{~cm}$, glabrous except on margins and main veins of the abaxial surface where stipitate glandular trichomes are found, with pocket domatia on the axils of primary and secondary veins, with 
Table I. Morphological and geographical summary of Martinella species, based on Gentry (1977, 1982, 2009) and pers. obs.

\begin{tabular}{c|c|c|c}
\hline Character & M. insignis & M. iquitoensis & M. obovata \\
\hline Leaflet texture & membranous & coriaceous & membranous to coriaceous \\
\hline Leaflet shape & ovate & elliptic & ovate (elliptic) \\
\hline Leaflet base & cordate & cuneate & cordate to truncate (cuneate) \\
\hline Leaf domatia & pocket & absent & absent \\
\hline Tendril & trifid & simple (trifid) & trifid (simple) \\
\hline Inflorescence & compound dichasium & thyrse or panicle & raceme \\
\hline Calyx lobes & 5; aristate & 2-4; rounded & dark rounded \\
\hline Corolla color & yellow & dark purple & darple to red (lilac) \\
\hline Distribution & Eastern coast of Brazil & Amazon basin & $\begin{array}{c}\text { Antilles, Central America and Northern } \\
\text { South America through Amazon basin }\end{array}$ \\
\hline Soil preference & sandy & sandy & generalist \\
\hline
\end{tabular}

few glands concentrated near base and scattered along the mid-vein on the adaxial surface. Inflorescences compound dichasia, with up to 7 branching orders, 9.2-12.3 $\mathrm{cm}$ long, sparsely to densely covered with stipitate glandular trichomes; bracts linear to narrowly elliptic, $8.4-24.7 \times 0.8-3.4 \mathrm{~mm}$, densely covered with stipitate glandular trichomes; pedicels terete, $5.8-19.4 \mathrm{~mm}$, sparsely to densely covered with stipitate glandular trichomes. Flowers with calyx pale green, tubular (campanulate), 8.8-15.4 $\times 6.5-12 \mathrm{~mm}$, sparsely covered with stipitate glandular trichomes except densely covered at the base, with few glands near the apex; lobes 5 , very shallowly triangular, aristate, aristae $2.9-8.6 \mathrm{~mm}$ long, densely covered with stipitate glandular trichomes; corolla yellow, weakly curved, $29.5-48.3 \mathrm{~mm}$ long, tubular basal portion 12.7-18.9 long $\times 2.4-4.5 \mathrm{~mm}$ wide, upper campanulate portion 15.0-23.4 long $\times$ 9.2-17.2 $\mathrm{mm}$ wide, lobes subcircular, 3.8-9.8 $\times 6.1-10.9 \mathrm{~mm}$, with ciliate margins; stamens in two lengths, longer ones $11.4-17.3 \mathrm{~mm}$, shorter ones $12.1-15.8 \mathrm{~mm}$, thecae $2.4-3.0$ $\mathrm{mm}$, glabrous; staminode $1.1-3.6 \mathrm{~mm}$, glabrous; gynoecium $29.2-39.6 \mathrm{~mm}$ long; ovary glabrous; style glabrous; stigma rhomboid, glabrous; nectariferous disk 2.3-3.0 $\times 1.0-1.8 \mathrm{~mm}$. Capsules 33.6-73.0 × 1.1-1.2 cm, pubescent when immature, glabrous when developed. Seeds ca. $1.0 \times 4.6 \mathrm{~cm}$.

Distribution and habitat. Martinella insignis is restricted to the northern portion of the Brazilian Atlantic Forest, occurring predominantly in areas with sandy soils (Fig. 3).

Etymology. The species epithet means remarkable or clearly distinguishable. This epithet was probably selected by Alwyn Gentry as reference to the contrasting floral color among species of Martinella.

Phenology. Flowering specimens were collected between September and February and fruiting collections in January, September and November.

Conservation status. This species is considered Data Deficient [DD] according to IUCN Standards and Petitions Subcommittee (2014) since this taxon is only known from very few specimens, with little information about its distribution and abundance. Further field studies are needed so that its conservation status can be properly documented. 

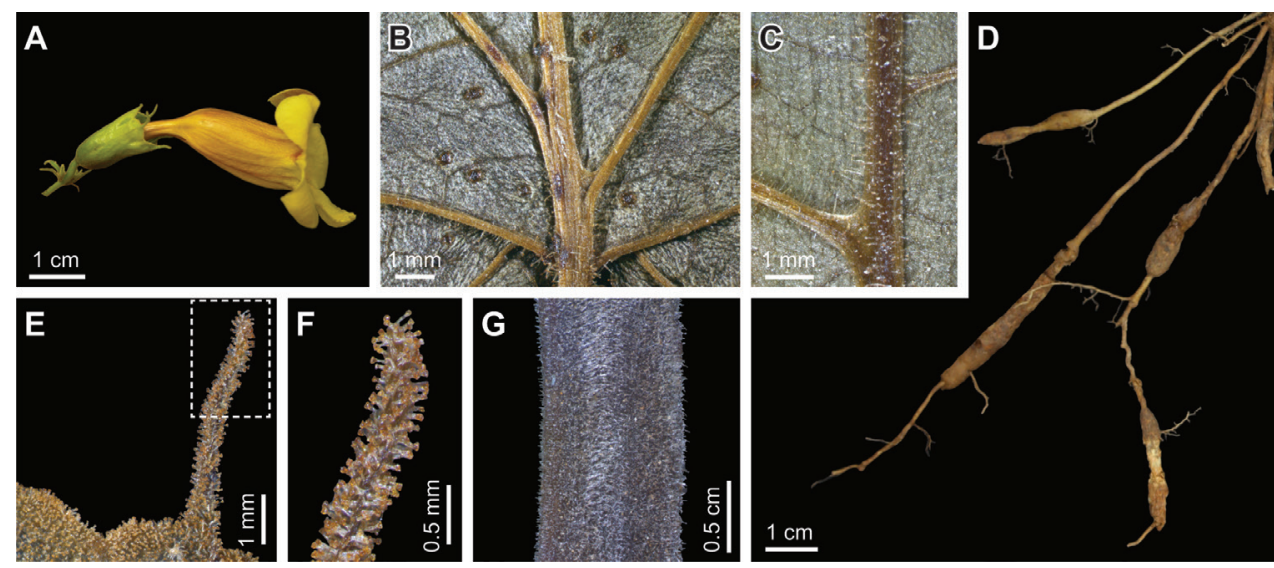

Figure 2. Details of Martinella insignis: A Flower B Leaflet base showing glands (abaxial face) C Mitedomatia between primary and secondary veins (abaxial side) D Root system with tuberous portions E Calyx detailing the aristae $\mathbf{F}$ Arista detail with glandular trichomes $\mathbf{G}$ Simple, tector trichomes on immature fruit. From Zuntini 151 (A-C, E, F), Zuntini 321 (D) and Demuner 4481 (G). Micrographs were obtained using focus stacking.

Discussion. Martinella insignis is the first species of Martinella found in the Atlantic Forest of Brazil. This new species clearly belongs to Martinella based on its prophylls, the continuous interpetiolar ridges and the corolla shape. However, M. insignis can be distinguished by the membranous leaflets, 5-lobed aristate calyces, and yellow corollas. In addition, $M$. insignis also has pocket-shaped leaf domatia (Fig. 2C) and a puberulous indument of glandular stipitate trichomes that covers almost all organs, with variable density (Fig. 2E-F). These trichomes may also be found in M. obovata and a few other species in Bignonieae, and are typically formed by a multicellular secretory head, supported by a uniseriate stalk (Nogueira et al 2013). Only corollas and fruits lack these; the corollas are glabrous, and fruits have simple, deciduous trichomes (Fig. 2G). Similar to the other species, the root system of $M$. insignis has unusual tuberous portions (Fig. 2D) that might represent an adaptation to the sandy soils, by accumulating water. However, the anatomical structure and function of these are yet unknown. Alwyn Gentry had already noted this new taxon, and had proposed the epithet "insignis" in sched.; his earlier findings are here accredited.

Additional collections examined. Brazil. Bahia: Guaratinga, Fazenda Vitória, 16³3'S, 3946'W, 29 October 1979, L.A. Mattos Silva \& H.S. Brito 634 (CEPEC, MO). Itabuna, Alcobaça para(ramal) S. Antonio, 24 January 1972, R.S. Pinheiro 1759 (CEPEC, MO). Itamaraju, S. Mori, L.A. Mattos Silva \& T.S. Santos 10743 (CEPEC, MO), Itamaraju, Fazenda Riacho das Pedras, prop. Sr. Gersino Antônio Bronzon, $17^{\circ} 08^{\prime} 48^{\prime \prime}$, $39^{\circ} 21^{\prime} 53^{\prime \prime W}, 12$ February 2007, R.A.X. Borges, A. Amorim, W.W. Thomas, L.C. Gomes, S. Sant'Ana \& O. Cruz 825 (CEPEC, SPF). Espírito Santo: Linhares, Reserva Natural da Companhia Vale do Rio Doce ("Reserva de Linhares"), MME, 1907'57.5"S, 4004'06.3"W, 65m, 14 December 2007, A.R. Zuntini, W.A.A. Pires \& G.S. Siqueira 


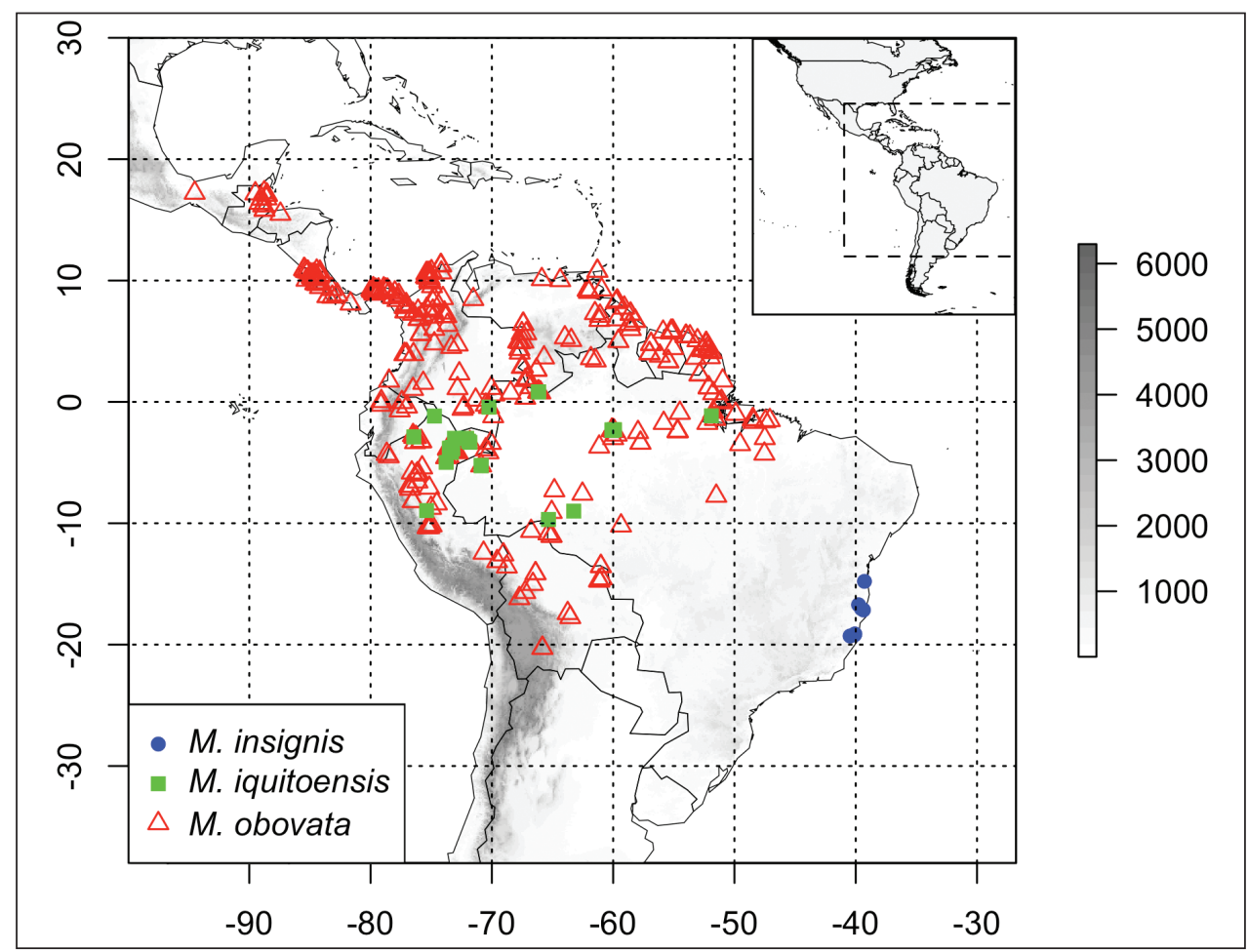

Figure 3. Distribution of Martinella species: M. insignis (solid blue circle), M. iquitoensis (solid green square) and $M$. obovata (open red triangles). Elevation in meters, according to the scale presented on the right.

151 (CVRD, RB, SPF), A.R. Zuntini, E. Françoso, J. Lopes \& V. Augusto 321 (SPF). Governador Lindenberg, Pedra de Santa Luzia, 420-590 m, 7 November 2007, V. Demuner, T.A. Cruz \& R.R. Vervloet 4481 (MBML, SPF). Sooretama, Mata de tabuleiro situada ao Noroeste da sede da Reserva da Sooretama, 14 July 1969, D. Sucre 5519 (RB-photo).

2. Martinella iquitoensis A. Samp., Ann. Acad. Bras. Sci. 7: 122.1935. http://species-id.net/wiki/Martinella_iquitoensis

Martinella manaosiana A.Samp., Bol. Mus. Nac. Rio de Janeiro 12(3, 4): 84.1936. TYPE: BRAZIL. Amazonas: Manaus, 25 July 1931, A. Ducke sn (holoype: RB24095!; isotype MO-2193049!, RB-24095 [second sheet]!)

Type. PERU. Loreto: Iquitos, 23 February 1924, J.G. Kuhlmann 1492 (holotype RB22027!; isotypes, MO-2192060!, RB-22027 [second sheet]!).

Distribution and habitat. This species is distributed widely in the Amazon basin (Brazil, Colombia, Ecuador, Peru and Venezuela), typically in sandy soils (Lohmann and Taylor 2014; Fig. 3). 
Conservation status. Martinella iquitoensis is distributed geographically through an area that is $<2000 \mathrm{~km}^{2}$, with seven Rapoport (1982) sub-populations known to date and $\geq 20 \%$ of its known individuals occurring outside Protected Areas, making it susceptible to the current reduction and degradation of its habitat. Therefore, this species is here considered as Vulnerable [VU B2ab(ii,iii)] according to the IUCN criteria (IUCN 2012; IUCN Standards and Petitions Subcommittee 2014).

Discussion. This species was distinguished by Sampaio from M. obovata based on the corolla color and size, leaflet texture and size, tendril type, and calyx indument. However these characters have proven to be fairly variable, especially in M. obovata, leading to morphological overlap between those taxa. The lack of a clear morphological discontinuity combined with the sympatric distributions, make these species hard to separate. Moreover, the difficulty in delimitating these two species can be observed in the few treatments that dealt with those species, which is particularly evident in the contrasting species keys presented (Sampaio 1935; MacBride 1961; Gentry 1982; Gentry 2009).

A character that might help telling these species apart is the inflorescence structure: a thyrse or panicle in $M$. iquitoensis versus a raceme in $M$. obovata. This character, combined with leaflet base, is here proposed as diagnostic for each species; however, the examination of additional material is necessary to validate its usefulness and consistency.

\section{Martinella obovata (Kunth) Bureau \& K.Schum., in Mart., Fl. Bras. 8(2): 161, tab. 84. 1896.}

http://species-id.net/wiki/Martinella_obovata

Spathodea obovata Kunth, Nov. Gen. Sp. (quarto ed.) 3: 147. 1818. [1819].

Bignonia obovata (Kunth) Spreng., Syst. Veg. 2: 830. 1825.

Macfadyena obovata (Kunth) Miers, Proc. Roy. Hort. Soc. London 3: 200.1863.

Type. COLOMBIA. Turbaco, s.d., Humboldt and Bonpland 1391 (holotype, P-Bonpl. [P00670823]!)

Distribution and habitat. This species is found from Central America and the Antilles through northern South America to the southern Amazon basin, in the Antilles, Belize, Bolivia, Brazil, Colombia, Costa Rica, Ecuador, French Guiana, Guatemala, Guyana, Honduras, Mexico, Panama, Peru, Surinam, and Venezuela, in different soil types and habitats (Lohmann and Taylor 2014; Fig 3).

Conservation status. Martinella obovata is distributed geographically through an area that is $\geq 2000 \mathrm{~km}^{2}$, with $<20 \%$ of its known individuals occurring outside Protected Areas, and seventy-two Rapoport (1982) sub-populations known to date. Therefore, this species is here considered as Least Concern [LC] according to the IUCN criteria (IUCN 2012; IUCN Standards and Petitions Subcommittee 2014).

Discussion. This species is the most variable and has the largest distribution in the genus (Central America and Caribbean throughout Amazon basin). Such variation is 
product of its phenotypic plasticity and wide ecological range, and is responsible for making this species hard to be distinguished from $M$. iquitoensis (as discussed above). Nonetheless, this high variation may also be seen as an evidence of a species complex, in which case, additional studies would be needed. For a complete list of synonyms see Gentry (1977).

\section{Acknowledgments}

We thank CNPq for an undergraduate fellowship to ARZ (113717/2006-7) and a Pq-1 grant to LGL; FAPESP for a research grant to LGL (2011/50859-2), two FAPESP/ BIOTA-NSF/Dimensions of Biodiversity Grants (2012/50260-6 and 2013/50297-0), and Vale S.A. for financial and logistic support. We also thank Dr. Charlotte Taylor for her review and significant comments on this manuscript; Iván Jiménez, Seema Sheth and Trisha Consiglio for assistance with the establishment of the conservation status of taxa; the editor and anonymous reviewers for their constructive remarks; Dr. Rafaela Forzza (RB) and Dr. Adriana Lobão (UFF) for providing images of specimens; Klei Sousa for the illustration and Geovane Siqueira for assistance during field work.

\section{References}

Baillon HE (1888) Bignoniaceae. In: Histoire des plantes 10(53). Libraire Hachette \& Co., Paris, 1-58.

Gentry AH (1974) Coevolutionary patterns in Central American Bignoniaceae. Annals of the Missouri Botanical Garden 61(3): 728-759. http://www.jstor.org/stable/2395026, doi: $10.2307 / 2395026$

Gentry AH (1977) Bignoniaceae. In: Flora of Ecuador (7). University of Gothenburg, Stockholm, $1-173$.

Gentry AH (1982) Bignoniaceae. In: Flora de Venezuela 8(4). Fondo Editorial Acta Científica Venezolana, Caracas, 1-433.

Gentry AH (2009) Bignoniaceae. In: Flora de Colombia 25. Universidad Nacional de Colombia, Bogotá, 1-462.

IUCN (2012) IUCN Red List Categories and Criteria: Version 3.1. Second edition. IUCN, Gland, Switzerland and Cambridge, UK.

IUCN Standards and Petitions Subcommittee (2014) Guidelines for using the IUCN red list categories and criteria. Version 11. Prepared by the Standards and Petitions Subcommittee. http://www.iucnredlist.org/documents/RedListGuidelines.pdf

Lohmann LG (2006) Untangling the phylogeny of neotropical lianas (Bignonieae, Bignoniaceae). American Journal of Botany 93(2): 304-318. doi: 10.3732/ajb.93.2.304

Lohmann LG, Bell CD, Calió MF, Winkworth, RC (2013) Pattern and timing of biogeographical history in the Neotropical tribe Bignonieae (Bignoniaceae). Botanical Journal of the Linnean Society 171(1): 154-170. doi: 10.1111/j.1095-8339.2012.01311.x 
Lohmann LG, Ulloa Ulloa C (2013) Bignoniaceae. In: iPlants prototype checklist. http:// www.iplants.com [accessed 17.08.2013]

Lohmann LG, Taylor CM (2014) A new generic classification of Bignonieae (Bignoniaceae) based on molecular phylogenetic data and morphological synapomorphies. Annals of the Missouri Botanical Garden 99(3): 348-489.

MacBride JF (1961) Bignoniaceae. In: Flora of Peru. Publications of the Field Museum of Natural History, Botany Series 13 (5C / 1): 3-101.

Nogueira A, El Ottra JHL, Guimarães E, Machado SR, Lohmann LG (2013) Trichome structure and evolution in Neotropical lianas. Annals of Botany 112: 1331-1350. doi: 10.1093/ aob/mct 201

Radford AE, Dickison WC, Massey JR, Bell CR (1974) Vascular Plant Systematics. HarperCollins, New York, USA.

Rapoport EH (1982) Aerography: Geographical Strategies of Species. Pergamon, New York, USA.

Sampaio AJ (1935) Novas especies de Bignoniaceas. Annaes da Academia Brasileira de Sciencias $7(2): 111-127$.

Thiers B (2013) Index Herbariorum: A global directory of public herbaria and associated staff. New York Botanical Garden's Virtual Herbarium. http://sweetgum.nybg.org/ih/ 